\title{
Miguel Y RAMón, dos PÁJAROS SOLITARIOS
}

\author{
Santiago Delgado \\ Real Academia Alfonso X el Sabio
}

Me llegó noticia de que sí, de que llegaron a conocerse estos dos creadores murcianos, que alcanzaron el reconocimiento pleno en la sociedad literaria española. Aunque no sé si eso de la sociedad literaria española existe o existió. Mucho menos la murciana, claro. A buen seguro que ellos no la conocieron, como buenos pájaros solitarios. Únicamente, la lejanía en el tiempo permite hablar de ambos a la vez, conjunta, pero separadamente. Ambos eran inimitables, salvo en el pastiche. Y ambos adolecieron/gozaron de una individualidad manifiesta hasta rozar lo insociable. Derecho a la intimidad, naturalmente.

Se da el caso de que los creadores que se movieron en su órbita personal, que no creativa, fueron los mismos en ambos casos, los poetas Eloy Sánchez Rosillo y José Rubio Fresneda, el novelista García Montalvo, y los pintores Avellaneda y Pedro Serna; aunque éstos poco pasaban a la vertiente literaria. No era una situación de discipulaje, aunque no tanto en el caso del pintor Pedro Serna, que supo captar el lirismo que había en la manera de entender la pintura del Maestro. Esta pléyade, sin otro sentido que el prístino significado, positivo, de la palabra, acompañó, en el plano personal, cuando la situación lo requería, a los dos pájaros solitarios de esta ciudad, que dejaba atrás siglos de condición levítica y tradicional.

En cierto modo, y sin pretender sentar cátedra de nada, las señas de identidad de ambos podrían incidir en un hecho que propongo: son las últimas, y excelentes, muestras de aquella «Deshumanización del Arte», que Ortega propugnó en 1925. El filósofo divulgador español pretendía crear un concepto que ayudase a comprender y aceptar a las vanguardias. Para él, la reclusión del arte en la exclusiva expresividad del autor era una deshumanización. Gaya y Espinosa reducen, para ampliarlo en flagrante oxímoron que reconozco, el concepto de realismo, incluso el de naturalismo. Para el arte del siglo XX, el arte ya no era «un espejo a lo largo del camino», como propugnó Stendhal. Para las vanguardias, al menos, ya no era eso. Apresurémonos a indicar el horror extremo que sentía Gaya por las vacuas vanguardias con las que coincidió en el París de 1928. Tras haber visto la «Roca del Prado» descreyó para siempre de la arbitrariedad y la extravagancia como ímpetus creadores del Arte. Con 
todo, un algo del Cubismo sí se puede rastrear en la obra, inmediata y posterior, del Maestro. Un algo, aclaramos y repetimos.

En cuanto a Espinosa, en la senda mental del profesor Tierno Galván, que fue su profesor en la Universidad de Murcia, destaquemos su famosa frase «las novelas no deben contar historias». El arte humanizado del que partía Ortega, para apartarlo de la modernidad, eran las novelas de Galdós o los cuadros de los Madrazo. Las vanguardias negaban el análisis y el mérito del oficio. El arte, si liberado, ya no respondía a unas coordinadas, externas al autor, de un aquí y un ahora, que arropan a un quién o a unos quiénes. El arte compete, desde las Vanguardias, a la exclusiva voluntad del creador. Y ahí viene la orteguiana deshumanización: a la presencia de una otra realidad que la objetiva, en el lienzo, en la materia escultórica y en el papel.

Y, bien, nuestra propuesta es que tanto Gaya como Espinosa son el último dato de esta deshumanización orteguiana. Con independencia de que luego haya habido una involución en esta deriva: la novela histórica y el hiperrealismo han sido reacciones a la deshumanización, siempre en el sentido orteguiano de la palabra. Recién estaba dicha, que no escrita, la afirmación de Espinosa antedicha, cuando este cronista le contestó desde su sección en el Suplemento Literario de La Verdad, que, a pesar de su dictamen sobre la novela sin historia, la novela, en todos los tiempos habría de «ensuciarse» con personajes, con lugares, con acciones y con tiempos pasados y presente. Y así fue. La novela ontológica que él propugnaba era intransferible e inimitable. Caso único.

Apuntemos que la deshumanización del Arte tuvo su brillante epígono casi medio siglo más tarde con el crítico de arte y político Rubert de Ventós, con su obrita El arte ensimismado (1963), que daba un paso más en entender y explicar el abandono de lo tradicional por los creadores. A falta de referente de prestigio, el Arte pasó a fijarse en sí mismo como referente preferencial, en una suerte de endogamia creativa. Ortega señaló el desdén por la realidad, Ventós señaló al mismo arte como cuna creativa, en sustitución de esa realidad como referente.

Ramón Gaya desarrolla su teoría del arte, tanto en prosa como en verso. Magistralmente en ambos territorios. El Maestro, forjado en el 27 y en el exilio mexicano y romano, sostiene que el formidable andamiaje del realismo finisecular de la pintura, que hemos significado en los Madrazo, está ya caduco. La misión del pintor es desbrozar todo lo que sobra en el realismo integral, dejando desnudo el referente, el alma del referente. Una impresión que coincide, en parte, con el concepto zen de lo oriental. Muchas veces, parte del lienzo manchado por Gaya permanece en blanco. El objetivo es necesitar el mínimo de trazos y manchas, para extraer lo que de sagrado tiene la realidad. Gaya hace, y patenta, la metáfora del sagrario, la realidad completa; y lo sagrado, aquello que sustenta como alma esa realidad. 
El pintor, el artista, debe indagar qué elementos son esos mínimos esenciales que transmiten esa realidad sagrada que es el referente. La pintura, sin un referente real (esto es, sagrado), no es nada, es capricho, extravagancia. Gaya dixit.

En cuanto a Espinosa, ya se desmarcaba del Realismo con su idea, antecitada, de la separación argumento-novela. Espinosa, como Gaya, busca trascender esa realidad que se presenta como fondo de su quehacer narrativo. Espinosa busca un cierto esencialismo en su narrativa. Rehúye lo fenoménico y quiere dar en lo ontológico, más allá aún de lo esencial. En su opera magna, Escuela de Mandarines, construye una alegoría formidable del Régimen dictatorial en el que vivía. Y comienza por la Universidad, plena, según él, de endogamia y servilismo político. Pero todo en esa realidad imaginada de la Feliz Gobernación es trasunto de la España del Movimiento. La realidad está trascendida, no imitada servilmente, como en la novela social. Espinosa tardó en escribir y publicar su novela, nada menos que dieciocho años.

Ambos creadores entienden que el milagro no es reproducir, tampoco deconstruir, como se proclamaría en Francia; con un sentido español de la realidad, ambos buscan trascenderla sin traicionarla, y consiguen una voz propia, singularísima, pictórica y narrativa, si bien algo alejada de los circuitos comerciales y ciertamente restringida a los ámbitos de cierta élite intelectual que aún cree en la trascendencia del Arte.

La obra literaria de Ramón Gaya es epistolar y ensayística, con la excepción de su expresión poética, desarrollada en dos explosiones creativas, que no aparecieron aisladas, pues un delgado hilo de continuidad temporal las enlaza. Una, la primera, en su dolorosa experiencia de guerra. Otra, con la biografía definitiva y felizmente encauzada, acerca de su pensamiento sobre el arte. Espinosa explicó verbalmente su particular preceptiva sólo oralmente, en las contadas ocasiones en que se mostró en público antes de su precipitada muerte. Ambos parten de un No a lo que se hallaba como fundamento del quehacer creador. Si bien, como es natural, divergían entre sí, que no en el rigor de sus conclusiones.

Cabría preguntarse sobre el futuro de estas dos figuras, en un siglo XXI, que en la novela ha vuelto a la fórmula hic, nunc et quid. Y valgan como ejemplo las novelas de Arturo Pérez Reverte, que no trasgreden nada. Innovan desde la misma sustancia de la referencia de realidad de la que parte el autor, pero no desde fuera. En pintura, en cambio, sí que ha habido una diversificación de perspectivas. Y junto con el hiperrealismo se han desarrollado escapismos a la realidad, más o menos consistentes, que, a pesar de todo, han dado en una deshumanización más libre y comprensible que el abstracto puro y duro de la época de la Guerra Fría, que tanto auge dio a este tipo de arte para contraponerlo al realismo bélico y heroico del Este del «telón de acero». Aunque también floreció en el México de la Revolución con 
los murales pedagógicos, que tantos disgustos causó al exiliado Ramón Gaya por oponerse a ese adocenamiento pictórico.

De «pájaros solitarios» Gaya y Espinosa acaso estén pasando a ser raras avis en el devenir de la trayectoria de la evolución artística, Literatura incluida. Pero hay que decirlo enseguida. Ese devenir histórico ya no es espontáneo, libre. El mercado, artístico y literario, domina a la calidad y la hace esclava de los designios monetarios de la oferta estética convertida en negocio. Y los gustos y aficiones de la masa demandante de producción de arte se hallan manipulados por encuestas, sistemas de distribución y campañas de influencia en el gusto. Todo ello redunda en el paulatino olvido por las masas, a las que obras como las de Gaya y Espinosa, podría redimir en el plano del espíritu.

Así no sea. Amén. 